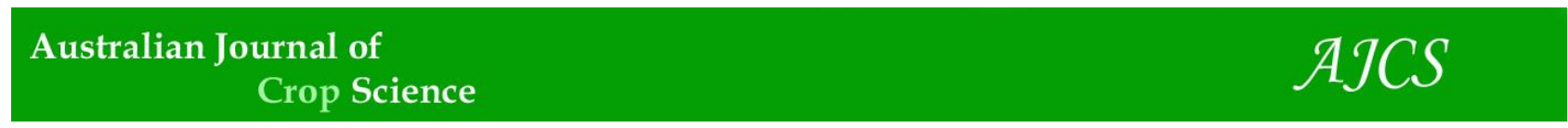

AJCS 15(08):1204-1216 (2021)

ISSN:1835-2707

doi: 10.21475/ajcs.21.15.08.p3360

\title{
Taxonomic significances of seed morphology in some tribes of subfamily Malvoideae
} (Malvaceae) in Saudi Arabia

\author{
Kadry Abdel khalik ${ }^{1,2 *}$, Suad Al-Ruzayza ${ }^{1}$, Ahmed Farid ${ }^{3}$ \\ ${ }^{1}$ Biology Department, Faculty of Applied Science, Umm-Al-Qura University, Makkah, Saudi Arabia \\ ${ }^{2}$ Botany and Microbiology Department, Faculty of Science, Sohag University, Sohag, Egypt \\ ${ }^{3}$ Botany and Microbiology Department, Faculty of Science, Assiut University, Assiut, Egypt
}

\section{*Corresponding author: Kadry3000@yahoo.com}

\begin{abstract}
In this study, we evaluated the taxonomic significance and seed macro and micromorphological characteristics of 28 species belong to eight genera of subfamily Malvoideae (Malvaceae) from Saudi Arabia. The genotypes were studied using light and scanning electron microscope (SEM). Macro- and micromorphological characters of the seeds are presented, including shape, color, size, hairs, surface pattern, epidermal cell shape, anticlinal boundaries, and periclinal cell wall. The taxonomic and phylogenetic implications of seed coat micromorphology were compared with those of the available gross morphological and molecular data (ISSR and SCOT). Seed character analysis offered useful data for evaluating the taxonomy of Malvoideae on both intrageneric and tribal levels. Monophyly of the genera Abutilon, Malva and Pavonia was supported. Moreover, these analyses supported previous phylogenetic data, indicating that distinct lines are present within the genus Hibiscus and Sida, indicating that these genera are not monophyletic. A key is provided for identifying the investigated taxa based on seed characters.
\end{abstract}

Keywords: Malvoideae, Cluster analysis, scanning electron microscopy, seed coat, tribal classification.

\section{Introduction}

Malvaceae Juss. are large family divided into more than 200 genera and over 4000 species (Abid et al., 2016; Chaudhary, 1999). It is widely spread and adapted to nearly all habitats and altitudes. It is distributed in tropical, subtropical and temperate regions (El Naggar, 2001). According to (APG, 2003, 2009; Bayer and Kubitzki, 2003; Chase et al., 2016), Malvaceae and its allied families (Bombacaceae, Sterculiaceae and Tiliaceae) are combined within the expanded family Malvaceae and divided into nine subfamilies: Bombacoideae Burnett, Brownlowioideae Burett, Sterculioideae Beilschm., Malvoideae Burnett, Dombeyoideae Beilschm., Grewioideae Dippel, Helicteroideae Meisn., Tilioideae Arn. and Byttnerioideae Burnett. Subfamily Malvoideae has been emerged as a monophyletic group based on both molecular and morphological data (Alverson et al., 1999; Bayer et al., 1999; Judd and Manchester, 1997). According to Bayer and Kubitzki (2003), Malvoideae has been divide into four tribes: Gossypieae Alef., Hibisceae Rchb., Kydieae Bates, and Malveae J. Presl. The number of species and genera of Malvaceae in Saudi Arabia has varied over the time. Migahid (1978) recognized 15 species within nine genera, while Collenette (1985) recorded 24 species belonging to 10 genera. Finally, Abedin et al. (1999) updated the number of species to 31 in 17 genera including 8 verities. Subfamily Malvoideae in the flora of Saudi Arabia, is represented by only three tribes: i.e.: Hibisceae, Gossypieae, and Malveae (Abedin et al., 1999). Two tribes were selected in the current study (Hibisceae and Malveae). Contributions that used seed-coat ornamentations to study taxonomic correlations within the selected two tribes in Saudi Arabia are limited. The few available works on the subfamily Malvoideae do not clarify the diversity with tribal considerations (Karakish et al., 2020; Taia, 2009).

Using scanning electron microscopy to reveal seed-coat characteristics has been early discussed (Barthlott, 1981). Micro-morphological data of the seed-coat surface provide stable taxonomic characteristics for many plant groups (Carvalho et al., 1999; Erol et al., 2006; Fawzi, 2011; Zareh et al., 2017; Abdel Khalik 2010, 2013, 2016). Seed surface sculpturing in the Malvaceae has been the subject of several works (Abid et al., 2016; El Naggar, 2001; Fawzi, 2018; Masullo et al., 2020; Özbek and Uzunhisarcikl, 2020).

The main aim of this study is to evaluate the taxonomic significance of seed macro and micromorphological characters in distinguishing between closely related taxa. To achieve this purpose, the seeds of 28 species (8 genera) of subfamily Malvoideae (Malvaceae) from Saudi Arabia were studied using light and scanning electron microscope (SEM).

Results

Results of seed size, shape, apex, base, color, type of indumentum, position of hilum, surface sculpturing, epidermal cell shape, anticlinal boundaries and periclinal cell wall were examined and summarized for each taxon (Tables 3 and 4). The SEM micrographs of seeds outline surface topography and seed coat enlargement were illustrated (Figures 1-12). 


\section{Seed Size}

The seed dimensions $(L \times W)$ exhibited a wide range of variations. Hibiscus aponeurus had the smallest size with $1 \mathrm{x}$ $1.5 \mathrm{~mm}$, while the largest size was found in Sida ovata with $3.3 \times 4.2 \mathrm{~mm}$ (Supplementary Table 1).

\section{Seed shape}

Three main seed shapes were recognized among the 28 species under investigation: reniform, ovate trigonous, Dshape. Most studied seeds were reniform. This type shows five subtypes: cordate reniform (in seven taxa of Abutilon, and five taxa of Hibiscus); rounded reniform (in four taxa of Malva, and Althaea ludwigii); deltoid reniform characterized only in Fioria vitifolia; broadly reniform recognized only to Senra incana; and ellipsoid reniform Sida alba, S. rhombifolia, and S. spinosa. The second type of seed shape (ovate trigonous) is more distinguished to the three members of Pavonia genus. Only Sida alii and S. ovata have D-shape seeds (Figs. 1-7).

\section{Seed sides}

Scanning electron microscopic micrographs shows three categories of seeds side: flat, convex, and concave. Flat seeds side were observed in Abutilon bidentatum, A. hirtum, Hibiscus purpureus, H. trionum, Malva neglecta, Sida alba, $S$. alii, S. ovata, and S. spinosa. Convex side was recorded in Abutilon figarianum, $A$. fruticosum, $A$. grandifolium, $A$. pannosum, Malva sylvestris, and Pavonia burchellii. The remaining taxa showed a concave seed side.

\section{Seed symmetry}

Seed symmetry is referred to the form of a seed in relation to the middle longitudinal line, if the parts on each side of the middle line are identical, the seed is symmetrical while if they are not equal the seed is being asymmetrical. Symmetrical seed observed in 8 taxa under investigation while the rest of taxa characterized by having asymmetrical seeds (Supplementary Table 1).

\section{Seed apex}

Results revealed three categories of seed apex: obtuse, truncate, and acute. Obtuse type is the dominant among the studied taxa. Truncate apex observed in the seeds of Hibiscus aponeurus and H. micranthus (Figs. $3.11 \& 4.13$ ) while acute apex recorded only in Fioria vitifolia (Fig.3.10).

\section{Seed base}

Out of 28 studied seeds, only two species found to have a truncate seed base: Sida alii and S. ovata (Fig. 7. 25, 26). The remaining taxa under investigation show a reniform seed base (Supplementary Table 1).

\section{Seed color}

Seed color can be regarded as a valuable diagnostic and systematic value among investigated seeds. Most of the studied taxa showed brown seeds with some degrees of variation from light to dark. Reddish brown only recognized to the seeds of Hibiscus deflersii. On the other hand, the seeds are black in both taxa of Abutilon grandifolium as well as Hibiscus aponeurus (Supplementary Table 1).

\section{Seed indumentum}

Presence or absence of seed indumentums varied greatly among the studied taxa and may be considered as a diagnostic character among the taxa under investigation.
Glabrous seed is the dominant character among the studied taxa (16 species). Hirtuse indumentum observed in seeds of Abutilon bidentatum, A. fruticosum, and A. ramosum (Figs. 1 . $1,3 \& 2.8$ respectively). Strigose recorded in the seeds of Abutilon figarianum, A. grandifolium, and Abutilon pannosum (Figs. 1. 2, 4 \& 2. 7 respectively). The seeds of Hibiscus deflersii, $H$. micranthus, and $H$. purpureus are easily recognized by their densely woolly indumentum (Figs. 3. 12 \& 4. 13, 14). Pavonia Arabica, P. triloba, and Senra incana shows a specific types of seed indumentum, sparsely pubescent in the former taxa and densely pilose in the later one (Figs. 5. $20 \& 6.22,23$ ).

\section{Hilum position}

Three types of hilum position were observed, central, subcentral and terminal. The central type is the dominant one among the studied taxa. Sub-central hilum position is recorded in seeds of Sida alba and S. rhombifolia (Figs. 6. 24 \& 7. 27). Seeds of both species Sida alii and S. ovata are easily recognized by the terminal hilum (Fig. 7. 25, 26).

\section{Surface topography}

Results of scanning electron microscopic micrographs exhibited four main categories of seed surface patterns (Supplementary Table 2): reticulate, foveate, alveolate, and rugose. Reticulate type is divided into 7 subtypes: reticulatefoveate (in Abutilon bidentatum, and Sida alba (Figs. 8. 1 \& 10. 24); reticulate-foveate, verrucate (in Abutilon figarianum, A. fruticosum, A. grandifolium, A. hirtum, A. pannosum, and $A$. ramosum (Fig. 8. 2, 4, 5, 7, 8); reticulatetransversely striate (in Althaea ludwigii, Sida alii, and $S$. ovata, Figs. 9.9 \& 11. 25, 26); reticulate-rugose with silky trichomes (in Hibiscus purpureus, Fig.9. 14); reticulatetransversely rugose (in Hibiscus trionum, and Pavonia arabica, Figs. 9. $15 \& 10.20)$; reticulate-rugose, foveolate in only Sida rhombifolia (Fig. 11. 27); reticulate-verrucate in Pavonia triloba (Fig. 10. 22). The second type of seed surface foveate may be foveate-verrucate or foveate-tuperculate in Abutilon muticum and Fioria vitifolia, respectively (Figs. 8. 6 \& 9. 10). The third alveolate type is characterized by rugose patterns to three taxa of genus Hibiscus, namely: $H$. aponeurus, $H$. deflersii, and $H$. micranthus (Fig. 9. 11, 12, 13). The last rugose type is subdivided into: rugose-transversely striate (in four Malva members (Figs. 9. 16 \& 10. 17, 18, 19); rugose, verrucate in only Sida spinosa (Fig. 11. 28); and finally, irregularly rugose in both Pavonia burchellii, and Senra incana (Figs. 10. 21, 23).

\section{Epidermal cell shape}

Five categories of epidermal cell shape were revealed by SEM: polygonal, penta-hexagonal, isodiametric, rectangular as well as irregularly undulate (Supplementary Table 2). Polygonal epidermal cells were characteristics to seven species: Abutilon bidentatum, A. fruticosum, A. hirtum, Althaea ludwigii, Hibiscus aponeurus, $H$. deflersii, and Hibiscus purpureus (Figs. 8. 1, 3, 5 \& 9. 9, 11, 12, 14). Pentahexagonal epidermal cells were recognized to ten species: Abutilon figarianum, A. grandifolium, A. ramosum, Hibiscus trionum, Pavonia arabica, P. triloba, Sida alba, S. alii, S. ovata, S. spinosa (Figs. 8. 2, 4, 8 \& 9. 15 \& 10. 20, 22, 24 \& 11. $25,26,28)$. Isodiametric epidermal cells were found in four species: Abutilon muticum, A. pannosum, Fioria vitifolia, and Sida rhombifolia (Figs. 8. 6, 7 \& 9. 10 \& 11. 27). The four species of studied Malva were recognized by having rectangular epidermal cells (Figs. 9. $16 \& 10.17,18,19$ ). 
While seeds of Hibiscus micranthus, Pavonia burchellii, and Senra incana exhibited irregularly undulate epidermal cells (Figs. 9. 13 \& 10. 21, 23).

\section{Anticlinal boundaries}

Anticlinal wall was raised in all taxa under investigation, being thin (in 13 taxa) or thick (in 15 taxa), the wall could be straight (in 18 taxa), straight to sinuous (in 5 taxa) or undulate (in 5 taxa), the surface of anticlinal wall was rough in most studied taxa and smooth in the remaining 10 taxa (Supplementary Table 2, Figs. 8-11).

\section{Periclinal cell wall}

Three periclinal wall were recorded among the studied taxa under investigation (Supplementary Table 2): Flat, concave, and sunken. Flat walls were subdivided into four subtypes: undifferentiated in Abutilon pannosum, Malva neglecta, $M$. sylvestris (Figs. $8.7 \& 9.16$ \& 10. 19), rugose in Abutilon fruticosum, A. hirtum, A. ramosum, Hibiscus trionum (Figs. 8. 3, 5, 8 \& 9. 15), verrucate in Malva verticillate, Pavonia arabica, Sida alba, S. spinosa (Figs. 10. 18, 20, 24 \& 11. 28), and transversely ridged in only Althaea ludwigii (Fig. 9. 9). Concave also subcategorized to six types: verrucate in Abutilon bidentatum, Fioria vitifolia, Hibiscus aponeurus, $H$. deflersii, H. micranthus, H. purpureus, Malva parviflora, Senra incana (Figs. 8. 1\& 9. 10, 11, 12, 13, 14 \& 10. 17, 23), verrucate to rugose in only Abutilon figarianum (Fig. 8. 2), verrucose to striate in only Sida alii, (Fig. 10. 24), seriate in Sida ovata (Fig. 11.26), rugose in Abutilon grandifolium (Fig. 8. 4), and pusticulate in Pavonia triloba (Fig. 10. 22). The later periclinal wall type (sunken) was recognized to Abutilon muticum, Pavonia burchellii, Sida rhombifolia (Figs. 8. 6 \& 10. 21 \& 11. 27).

\section{Key to the taxa under investigation}

1. Seeds D-shape or ovate trigonous ..................................... 2

Seeds reniform or nearly so .............................................. 6

2. Seeds D-shape, symmetric, flat sided, dark brown, with truncate base, terminal hilum ................................................ 3

Seeds ovate trigonous, asymmetric, convex or concave sided, brown, with reniform base, basal hilum ...................... 4 3. Seeds $2.3 \times 2.8 \mathrm{~mm}$, anticlinal wall foveate, periclinal cell wall verrucate to striate ............................................... Sida alii - Seeds $3.3 \times 4.2 \mathrm{~mm}$, anticlinal wall ribbed, periclinal cell wall striate Sida ovata

4. Seeds glabrous, side convex, surface rugose, epidermal cell undulate, priclinal wall sunken ............. Pavonia burchellii - Seeds sparsely pubescent, side concave, surface reticulate, epidermal cell penta-hexagonal, periclinal wall flat

concave...

5. Seeds less than $1.8 \mathrm{~mm}$ length, surface reticulatetransversely rugose, flat-verrucate periclinal walls ............................................................ Pavonia arabica Seeds more than $2 \mathrm{~mm}$ length, surface reticulateverrucate, concave-pusticulate periclinal walls .............................................................................. triloba 6. Seeds rounded reniform, surface scalariform ..................7 Seeds cordate, deltoid, ellipsoid, or broadly reniform, surface not as above.............................................................11 7. Seeds surface scalariform reticulate, epidermal cell elongated polygonal, periclinal wall transversely ridged Althaea ludwigii
- Seeds surface scalariform rugose, epidermal cell elongated rectangular, periclinal wall verrucate of undifferentiated .......................................................................... 8

8. Seeds side flat or convex, periclinal wall undifferentiated smooth

- Seeds side concave, periclinal wall verrucate rough

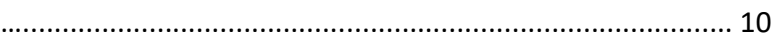

9. Seeds flat sided, symmetric, dark brown ........................................................................ Malva neglecta - Seeds convex sided, asymmetric, brown sylvestris

10. Seeds $1.4 \times 1.6 \mathrm{~mm}$ dim., symmetric, brown, periclinal wall concave................................................... Malva parviflora

Seeds $2.1 \times 1.8 \mathrm{~mm}$ dim., asymmetric, dark brown, periclinal wall flat ....................................... Malva verticillata

11. Seeds deltoid, ellipsoid or broadly reniform .................. 12 - Seeds cordate reniform

16

12. Seeds deltoid reniform, apex acute .............. Fioria vitifolia

- Seeds ellipsoid or broadly reniform, apex obtuse ......... 13 13. Seed broadly reniform, symmetric, brown, densely pilose, epidermal cells undulate

Senra incana

- Seed ellipsoid reniform, asymmetric, dark brown, glabrous, epidermal cells isodiametric or penta-hexagonal

14. Seeds side concave, epidermal cells isodiametric, anticlinal wall scabrate, periclinal wall sunken .................................................................. Sida rhombifolia

Seeds side flat, epidermal cells penta-hexagonal, anticlinal wall ridged, periclinal wall flat-verrucate

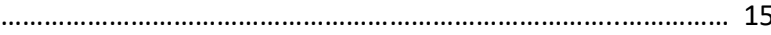
15. Seeds $1.6 \times 1.1 \mathrm{~mm}$ dim., hilum sub basal, surface reticulate-foveate.................................................... Sida alba

- Seeds 3.1 x $4.2 \mathrm{~mm}$ dim., hilum basal, surface rugoseverrucate ............................................................ Sida spinosa

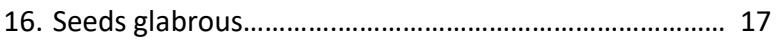

Seeds hairy .................................................................. 20

17. Seeds less than $1.2 \mathrm{~mm}$ length, black, apex truncate, surface alveolate ...................................... Hibiscus aponeurus

- Seeds more than $1.2 \mathrm{~mm}$ length, dark brown, apex obtuse, surface reticulate or foveate .................................... 18 18. Seeds side concave, epidermal cell isodiametric, periclinal wall sunken Abutilon muticum

- Seeds side flat, epidermal cell polygonal or pentahexagonal, periclinal wall flat-rugose ..................................... 19 19. Seeds surface reticulate-foveate, verrucate, epidermal cell polygonal Abutilon hirtum - Seeds surface reticulate-transversely rugose, epidermal cell penta-hexagonal ....................................... Hibiscus trionum 20 . Seeds covered with densely woolly indumentums .......... 21

Seeds covered with slightly indumentums .................... 23 21. Seeds more than $2 \mathrm{~mm}$ length, side flat, surface reticulate, rugose with silky trichomes ..... Hibiscus purpureus - Seeds less than $1.8 \mathrm{~mm}$ length, side concave, surface alveolate-rugose .................................................................. 22 22. Seeds apex obtuse, reddish brown, epidermal cell polygonal ...................................................... Hibiscus deflersii 
- Seeds apex truncate, light brown, epidermal cell undulate Hibiscus micranthus

23. Seeds symmetric . 24

Seeds asymmetric .26

24. Seeds side flat, indumentum hirtuse

Abutilon bidentatum

- Seeds side convex, indumentum strigose 25

25. Seeds black, epidermal cell penta-hexagonal, periclinal wall concave-rugose Abutilon grandifolium

- Seeds dark brown, epidermal cell isodiametric to angular, periclinal wall flat-undifferentiate ............ Abutilon pannosum

26. Seeds with strigose indumentum, periclinal wall concave, verrucate to rugose ................................. Abutilon figarianum

- Seeds with hirtuse indumentum, periclinal wall flat-

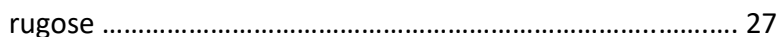
27. Seeds $1.8 \times 1.7 \mathrm{~mm}$ dim., epidermal cell polygonal, anticlinal wall ridged. Abutilon fruticosum

Seeds $2 \times 2.1 \mathrm{~mm}$ dim., epidermal cell penta-hexagonal, anticlinal wall ridged-foveate Abutilon ramosum

\section{Discussion}

Several authors have established classification systems to classify the family Malvaceae into subfamilies, tribes, and subtribes (Bentham and Hooker 1862, Kearney 1951, Schultze-Motel 1964, Hutchinson 1967, Bates 1968, Krebs 1994, La Duke and Doebley 1995). These studies were based on life forms, fruits, carpel morphology, and number and position of ovules in each carpel. Environmental conditions may change the morphological characters of the plants, which may affect the divergence during classification. Scanning electron microscopy of seeds would become a routine technique for furnishing information on seed coat morphology (Heywood 1969). Abdelkhalik (2002) recommended SEM in his studies of the structure of seed and pollen ornamentation in the Brassicaceae as being useful for taxonomic studies. In the present study, we used a number of seed characters based on details of the seed coat surface. UPGMA provided an insight into the degree of similarity among the species and showed whether they formed groups or clusters, indicating the range of variation within and among tribes. In general, results of seed morphological analyses proposed groups and partially established the tribes, subtribes, and section classification of Malvoideae as has been reported with traditional methods (Mattei 1915, Kearney 1951, Schultze-Motel 1964, Hutchinson 1967, Bates 1968, La Duke \& Doebley 1995), and molecular data (Fryxell 2002, Bayer \& Kubitzhi 2003, Tate et al. 2005, Reveal 2012).

\section{Tribes' classification}

\section{Tribe: Abutileae}

According to Hutchinson (1967), the tribe Abutileae comprises of two subtribes: Abutilinae (including Abutilon) and Sidinae (including Sida and Malvastrum). However, the tribe Abutileae is considered within Malveae in the system of Takhtajan (2009). Reveal (2012) separated both subtribes Abutilinae and Sidinae from Malveae under tribe Sidieae by using molecular data. The infrageneric classification of Abutilon is not properly understood. Previously, the genus has been ordered into sections and subsections. The results of a systematic revision of Abutilon (Mattei 1915) species distributed in Saudi Arabia were compared with the findings of this study. Mattei (1915) treated A. fruticosum under stirps Capsulati substirps Frutieosi; $A$. ramosum in stirps Capsulati substirps Cuspidati; $A$. figarianum in stirps Cephalocarpi substirps Graveolenti; $A$. hirtum, $A$. bidentatum, and $A$. grandifloium in stirps Cephalocarpi substirps Mierocarpi; and $A$. pannosum and $A$. muticum in stirps Cephalocarpi substirps Mutici. Fryxell (2002) treated $A$. bidentatum and $A$. grandifloium in section Beloere; $A$. muticum, A. figarianum, A. pannosum in section Muticum; and $A$. fruticosum in section Oligocaroae. Similarly, Tate et al. (2005) studied the phylogenetic relations within Malveae tribe based on sequence data from (ITS) regions of the 18265 nuclear ribosomal repeat and accepted two main clades: one comprising of Abutilon and Sida (Abutilon alliance) and a second covering the rest of taxa revealing that Abutilon, Sida, and Tetrasida are not monophyletic. Taia (2009) investigated the morphology-based systematic revision of five Abutilon species from Saudi Arabia. He found a close relationship between species and classified them into two groups.

According to the characters of seed, the studied taxa of Abutilon were grouped in one cluster that split into three groups. One clade comprised of A. bidentatum with 100 genetic similarities (Fig. 12). Brown seed, flat seed sides, and reticulate-foveate epidermal cell surface distinguish this species. The second group includes $A$. pannosum, $A$. grandifloium and $A$. figarianum, with 0.90 genetic similarities. All of the three species have cordate reniform seed shape, strigose seed hairs, reticulate-foveate, verrucate seed surface, and raised, thick, ridged anticlinal boundaries. The third group includes $A$. fruticosum, $A$. ramosum, $A$. hirtum, A. muticum, and two species of Hibiscus with 0.70 genetic similarities. This entire species have dark brown seed, reticulate-foveate, verucate surface pattern, raised, thick, ridged, and rough anticlinal boundaries. The results of this study suggest that the species of Abutilon is form a polyphyletic group. Our data support previous approach of distinctly treating tribe Abutileae (Reveal, 2012) and its two subtribes from Malveae. Therefore, these results are partially in line with Mattei (1915), Fryxell (2002), and congruent with the findings of Reveal (2012), Tate et al. (2005) and Fuertes Aguilar et al. (2003).

\section{Tribe. Malveae}

Bentham \& Hooker (1862), Hutchinson (1967), and Reveal (2012) treated Malva and Althaea as belong to the tribe Malveae. However, they preserved Sida in the tribes Malveae, Abutileae, and Sideae, respectively. Bates (1968) suggested that Malva might be polyphyletic as its chromosome number is in the range of $2 n=14$ and therefore, should be considered diploids, whereas species having chromosome number $2 \mathrm{n}=40-44$ are hexaploids. This number is related to Sida and other taxa. Furthermore, Luque \& Devesa (1986) reported hexaploids chromosome base number of $2 n=42$ in $M$. parviflora, $M$. neglecta, M. sylvestris, and dodecaploids (chromosome count $=76,84,112$ ) in $M$. verticillata. Besides, Fryxell (1997) reported that Sida is heterogeneous and has the same base chromosome number $x=7$ or $8(2 n=14,28 ; 2 n=16,32)$. Based on an ITS sequence analysis, Ray (1995) differentiated Malvoid and Lavateroid groups and placed all Malva species in the malvoid group. Aguilar et al. (2003) also studied the phylogenetic 
Table 1. List of plant specimens used in scanning electron microscope study.

\begin{tabular}{|c|c|c|}
\hline No & Taxa & Source and voucher \\
\hline 1 & Abutilon bidentatum Hochst. & Wadii Thalolah near AL-Baha, Suad Al-Ruzayza, 11 (UQU) \\
\hline 2 & Abutilon figarianum Webb & Wadii Qusai, Suad Al-Ruzayza, 5 (UQU) \\
\hline 3 & Abutilon fruticosum Guill. & Near Al-Howtah, Alfarhan and J. Thomas, 22274 (KSU) \\
\hline 4 & Abutilon grandifolium (Willd.) Sweet & Fifa mountain, Suad Al-Ruzayza,15 (UQU) \\
\hline 5 & Abutilon hirtum (Lam.) Sweet & Mahil Aseir, Suad Al-Ruzayza, 815 (UQU) \\
\hline 6 & Abutilon muticum Sweet & Alardah, Suad Al-Ruzayza,6 (UQU) \\
\hline 7 & Abutilon pannosum (G.Forst.) Schltdl. & Al-Edabi, Suad Al-Ruzayza, 17 (UQU) \\
\hline 8 & Abutilon ramosum (Cav.) Guill. \& Perr. & Shada mountiain, Suad Al-Ruzayza,2 (UQU) \\
\hline 9 & Althaea ludwigii L. & Qassim Road, Suad Al-Ruzayza, 22 (UQU) \\
\hline 10 & Fioria vitifolia (L.) Mattei & Al Darb, near Abha, Suad Al-Ruzayza, 21 (UQU) \\
\hline 11 & Hibiscus aponeurus Sprague \& Hutch & Fifa mountain, Suad Al-Ruzayza 38(UQU) \\
\hline 12 & Hibiscus deflersii Schweinf. & Taif, Suad Al-Ruzayza , 37 (UQU) \\
\hline 13 & Hibiscus micranthus L.f. & Raidah, Suad Al-Ruzayza, 34 (UQU) \\
\hline 14 & Hibiscus purpureus L. & Fifa mountain, Alfarhan and J. Thomas, 999 (KSU) \\
\hline 15 & Hibiscus trionum L. & Kew Garden, Millennium seed bank, Serial number: 0091154 (K) \\
\hline 16 & Malva neglecta Wallr. & Near Riyadh, Ushaqur, Suad Al-Ruzayza, 2 (UQU) \\
\hline 17 & Malva parviflora $\mathrm{L}$. & Alkarj, Suad Al-Ruzayza, 29 (UQU) \\
\hline 18 & Malva verticillata $\mathrm{L}$. & AL-ahsaa, Suad Al-Ruzayza, 32 (UQU) \\
\hline 19 & Malva sylvestris $\mathrm{L}$. & Al-Qasim, Buradah, Suad Al-Ruzayza, 46 ( UQU) \\
\hline 20 & Pavonia arabica Hochst. & Wadi Bani Zaher, S. Chaudhary, 7087 (RAWRC) \\
\hline 21 & Pavonia burchellii & Jeddah, Suad Al-Ruzayza, 40 (UQU) \\
\hline 22 & Pavonia triloba Guill. \& Perr & Kew Garden, Millennium seed bank, Serial number: 0084822 (K) \\
\hline 23 & Senra incana Cav. & Harrat Al-Shara, Suad Al-Ruzayza, 41(UQU) \\
\hline 24 & Sida alba L., & Fifa mountain, J. Thomas and R. Basahi, 21876 (KSU) \\
\hline 25 & Sida alii & Jabal Abadil, Turki, Mathew 19556 (KSU) \\
\hline 26 & Sida ovata & Kew Garden, Millennium seed bank, Serial number: 0493426 (K) \\
\hline 27 & Sida rhombifolia & Kew Garden, Millennium seed bank, Serial number: 0034687 (K) \\
\hline 28 & Sida spinosa. & Kew Garden, Millennium seed bank, Serial number: 0000686 (K) \\
\hline
\end{tabular}
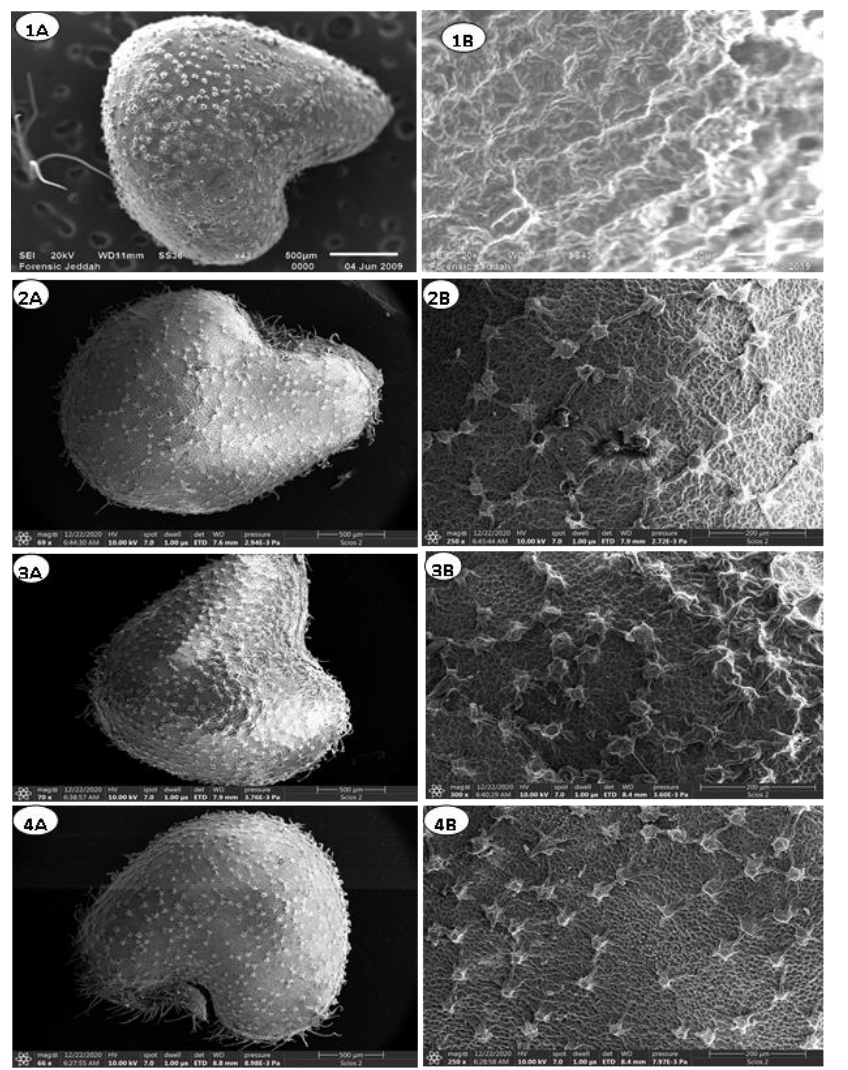

Figure 1. SEM micrographs of seeds. (A) Entire seed, (B) Surface. 1. Abutilon bidentatum; 2. Abutilon figarianum; 3. Abutilon fruiticosum; 4 . Abutilon grandifolium. 
Table 2. List of genera used in the current study (Chaudary, 1999), a comparison of the traditional (Bentham \& Hooker, 1862; Hutchinson, 1967) and phylogenetic classifications (Bayer \& Kubitzhi, 2003; Reveal's system, 2012).

\begin{tabular}{|c|c|c|c|c|}
\hline & $\begin{array}{c}\text { Bentham and Hooker } \\
\text { (1862) }\end{array}$ & Hutchinson (1967) & Reveal (2012) & Bayer \& Kubitzhi (2003) \\
\hline & Tribe / Subtribe & Tribe / Subtribe & Tribe / Subtribe & Tribe / Alliance \\
\hline Abutilon Mill. & Malveae / Abutilinae & $\begin{array}{l}\text { Abutileae / } \\
\text { Abutilinae }\end{array}$ & Sideae / Abutilinae & Malveae /Abutilon \\
\hline Sida L. & Malveae / Sidinae & Malveae / Sidinae & Sideae / Sidinae & \\
\hline Althaea $\mathrm{L}$. & Malveae / Eumalvinae & Malveae / Malvinae & Malveae / Malvinae & Malveae / Malva \\
\hline Malva L. & & & & \\
\hline Pavonia Cav. & Ureneae / - & \multirow[t]{4}{*}{ Hibisceae / - } & \multirow[t]{4}{*}{ Hibisceae / - } & \multirow[t]{4}{*}{ Hibisceae / - } \\
\hline Hibiscus L. & \multirow[t]{3}{*}{ Hibisceae / - } & & & \\
\hline Senra Cav. & & & & \\
\hline Fioria Mattei & & & & \\
\hline
\end{tabular}

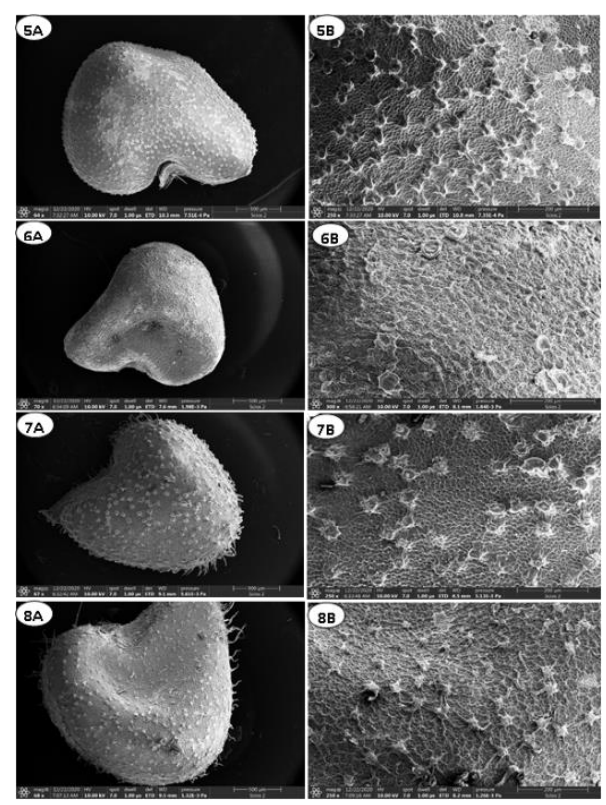

Figure 2. SEM micrographs of seeds. (A) Entire seed, (B) Surface. 5. Abutilon hirtum; 6. Abutilon muticum; 7. Abutilon pannosum; 8. Abutilon ramosum.
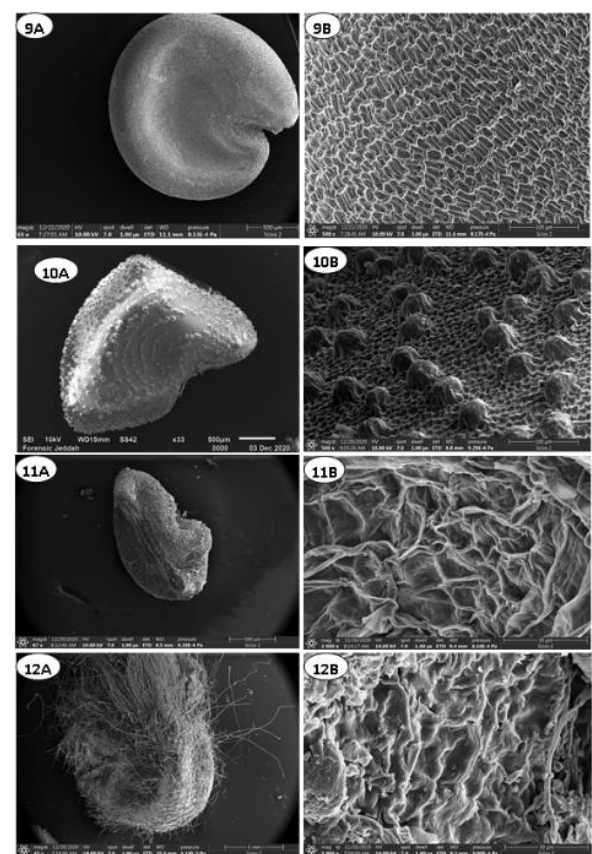

Figure 3. SEM micrographs of seeds. (A) Entire seed, (B) Surface. 9. Althaea ludwigii. 10. Fioria vitifolia. 11. Hibiscus aponeurus. 12. Hibiscus deflersii. 


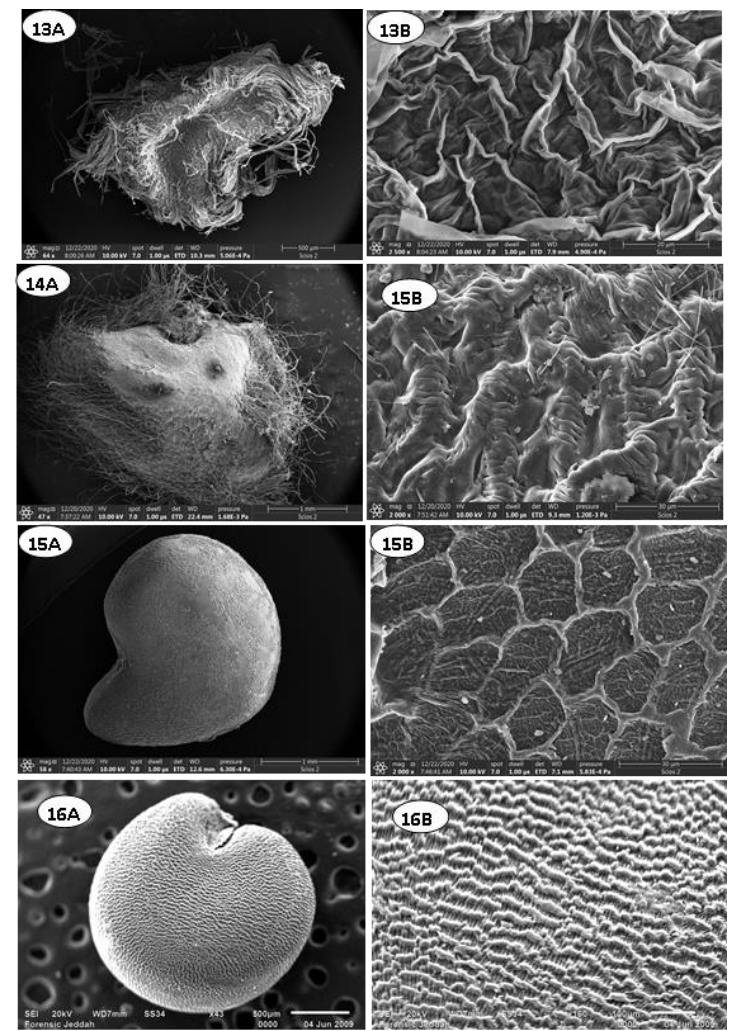

Figure 4. SEM micrographs of seeds. (A) Entire seed, (B) Surface. 13. Hibiscus micranthus; 14. Hibiscus purpureus; 15. Hibiscus trionum; 16. Malva neglecta.

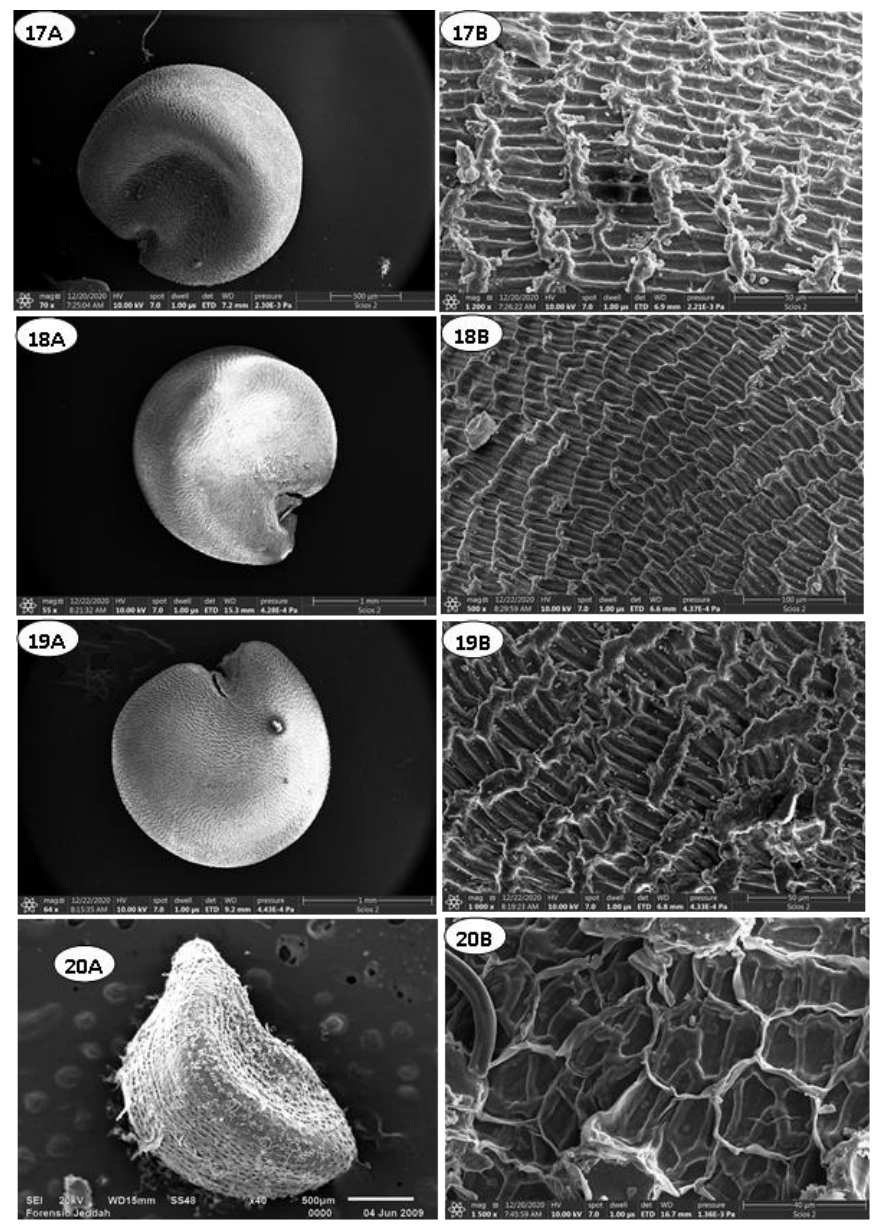

Figure 5. SEM micrographs of seeds. (A) Entire seed, (B) Surface. 17. Malva parviflora; 18. Malva verticillata; 19. Malva sylvestris; 20. Pavonia arabica. 


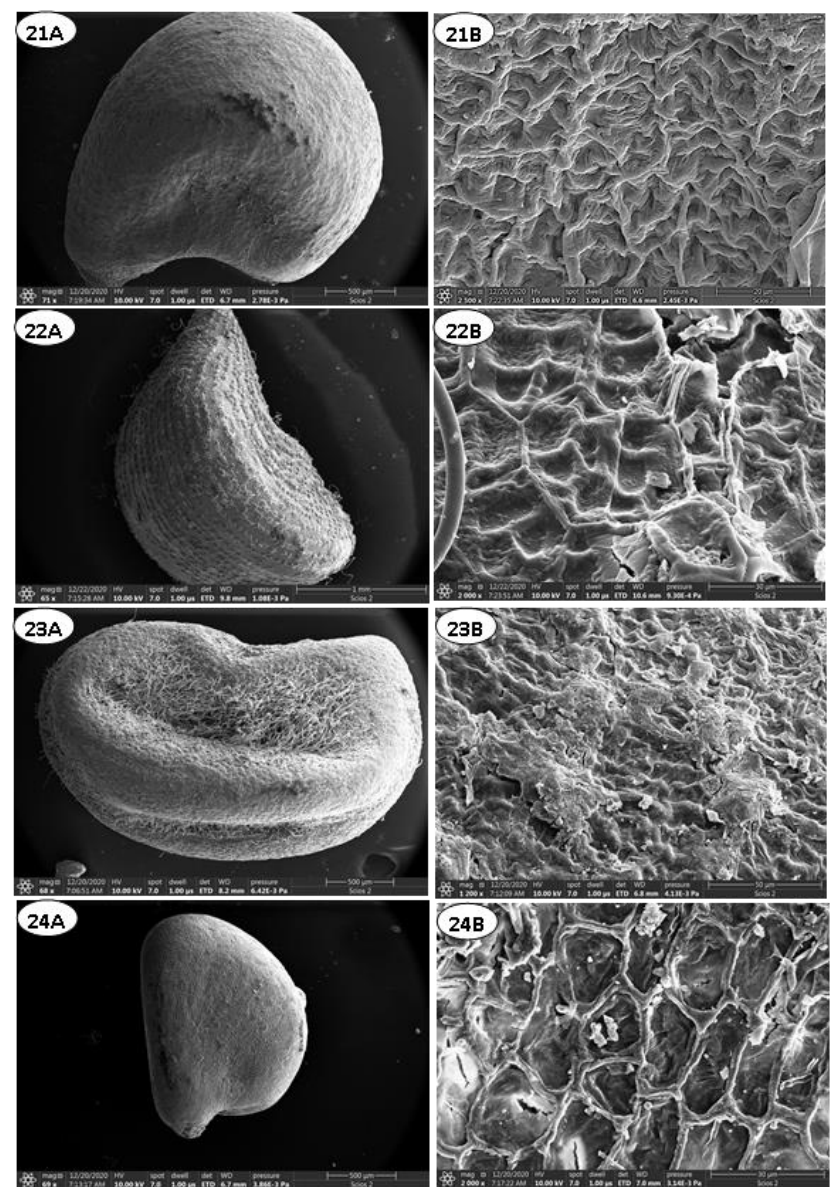

Figure 6. SEM micrographs of seeds. (A) Entire seed, (B) Surface. 21. Pavonia burchellii; 22. Pavonia triloba; 23. Senra incana; 24. Sida alba.
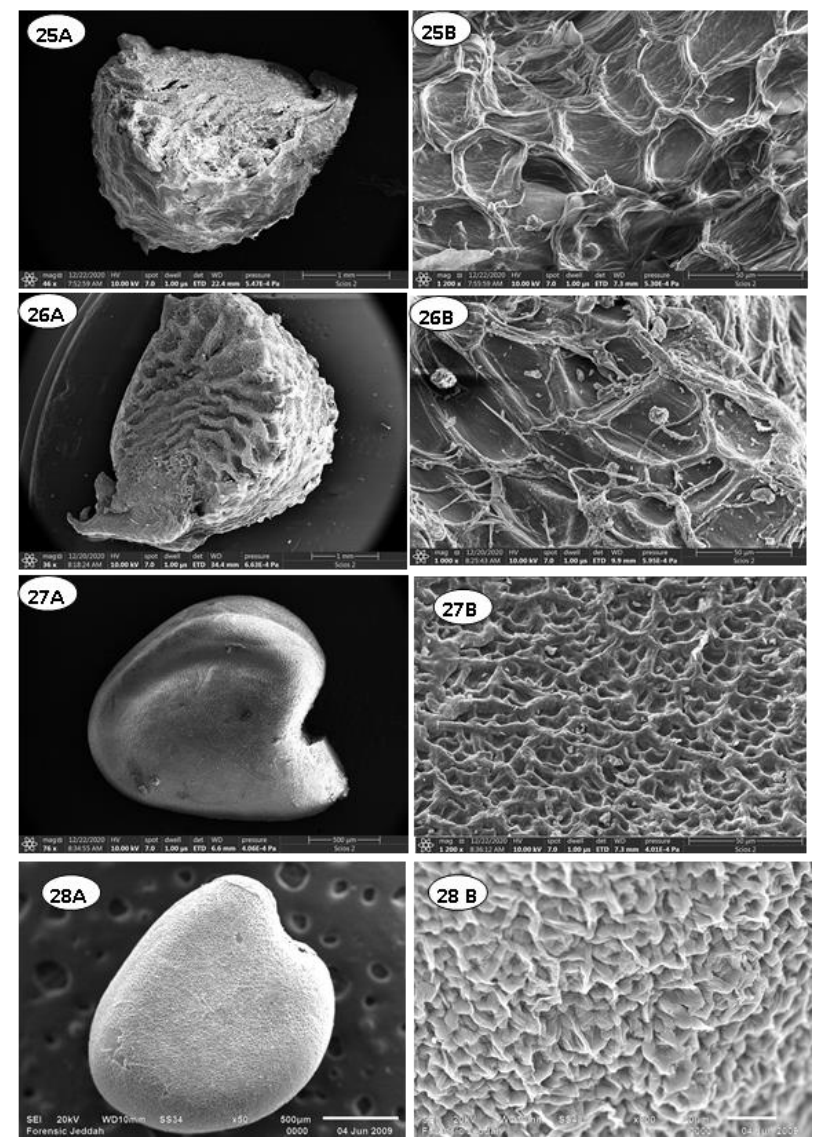

Figure 7. SEM micrographs of seeds. (A) Entire seed, (B) Surface. 25. Sida alii; 26. Sida ovata; 27. Sida rhombifolia; 28. Sida spinosa. 

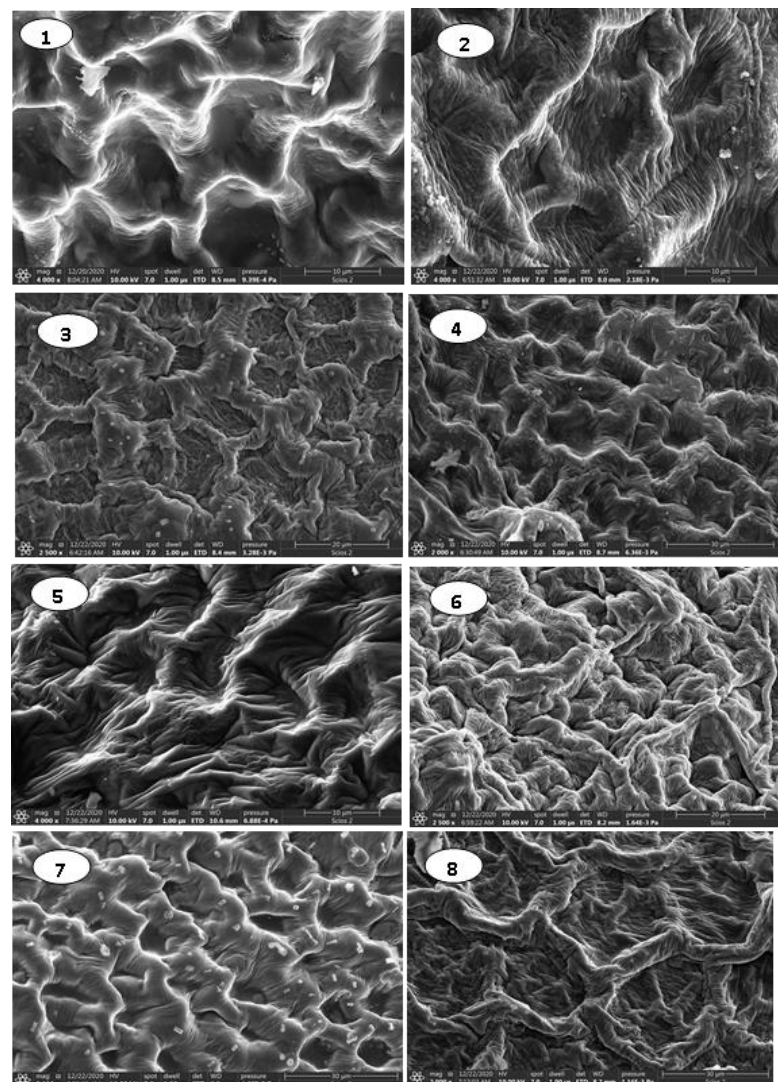

Figure 8. SEM micrographs of seeds: (Enlargement of seed coat). 1. Abutilon bidentatum; 2. Abutilon figarianum; 3. Abutilon fruiticosum; 4. Abutilon grandifolium; 5. Abutilon hirtum; 6. Abutilon muticum; 7. Abutilon pannosum; 8. Abutilon ramosum.
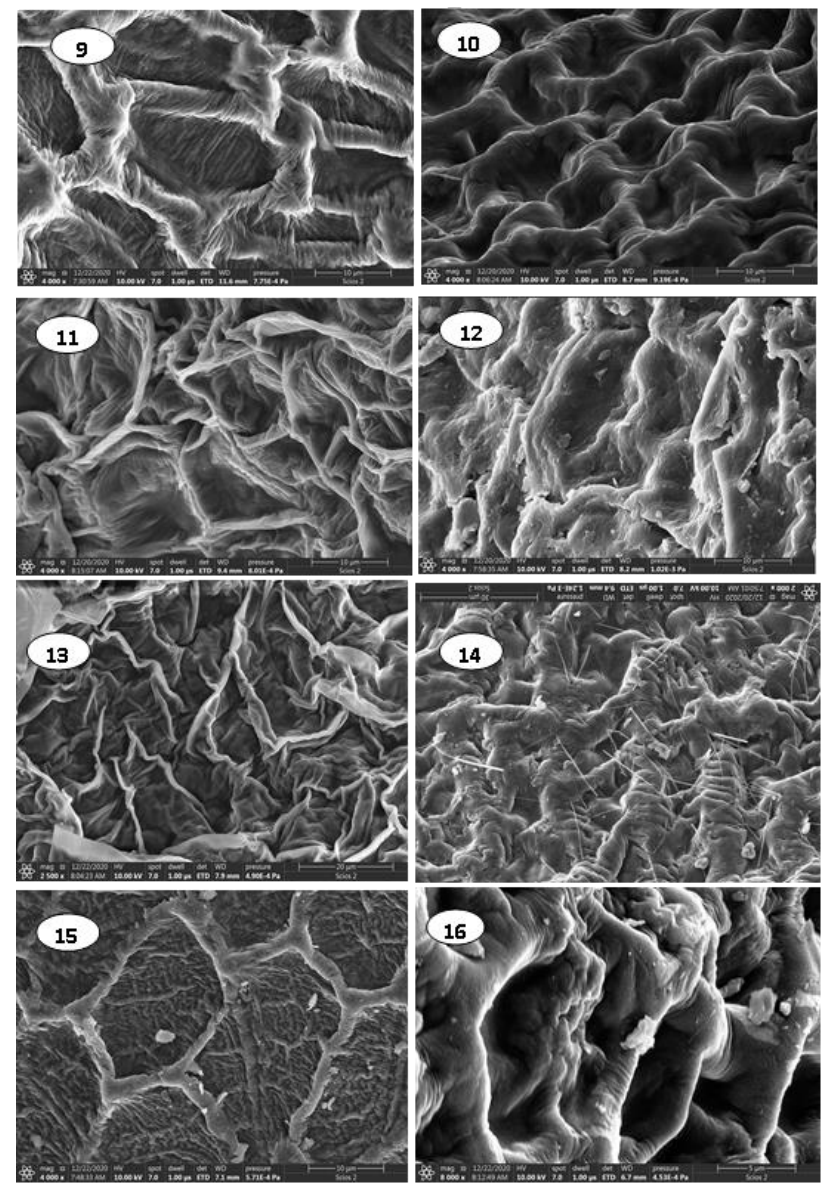

Figure 9. SEM micrographs of seeds: (Enlargement of seed coat). 9. Althaea ludwigii. 10. Fioria vitifolia. 11. Hibiscus aponeurus. 12. Hibiscus deflersii; 13. Hibiscus micranthus; 14. Hibiscus purpureus; 15. Hibiscus trionum; 16. Malva neglecta. 

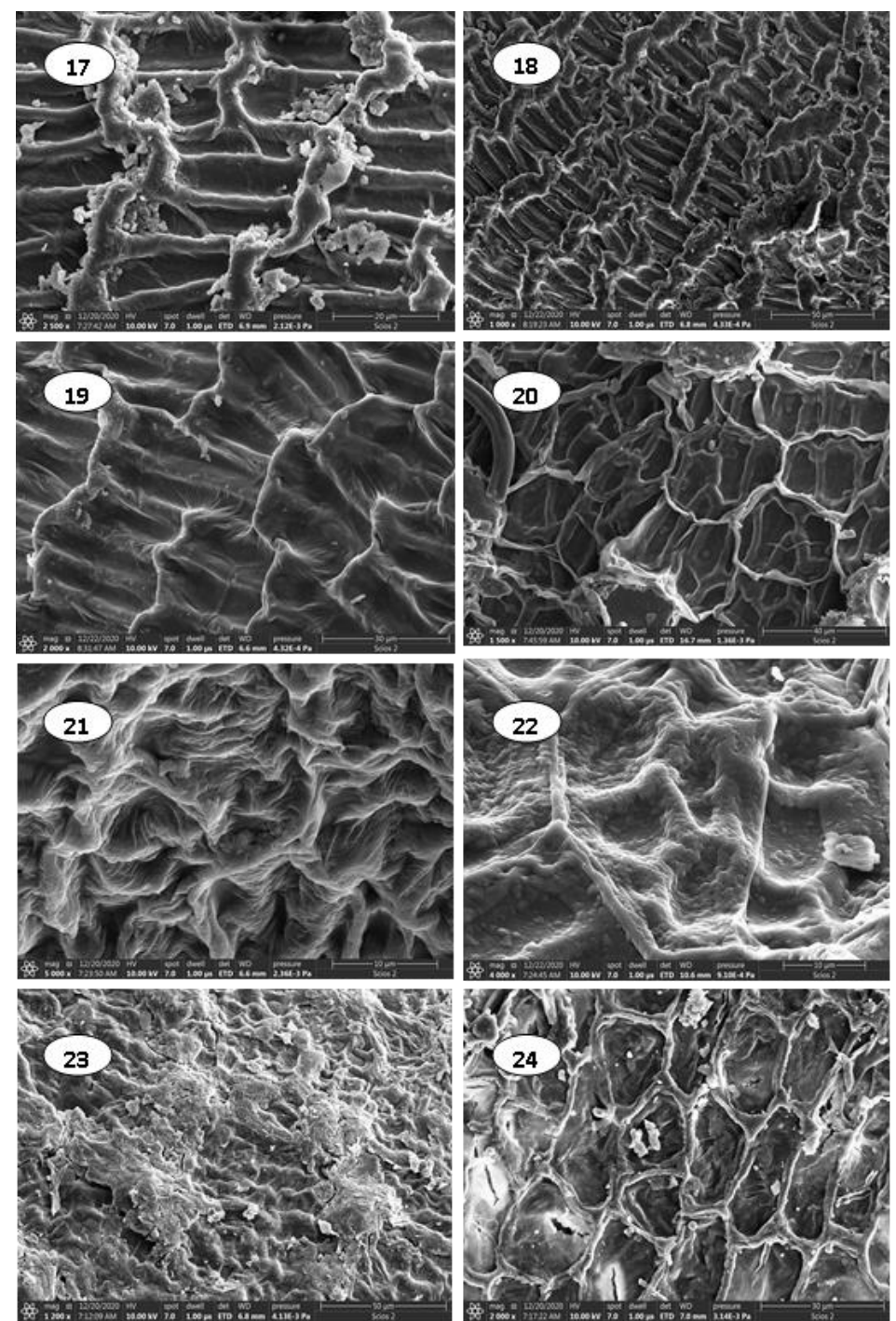

Figure 10. SEM micrographs of seeds: (Enlargement of seed coat). 17. Malva parviflora; 18. Malva verticillata; 19. Malva sylvestris; 20. Pavonia arabica; 21. Pavonia burchellii; 22. Pavonia triloba; 23. Senra incana; 24. Sida alba.
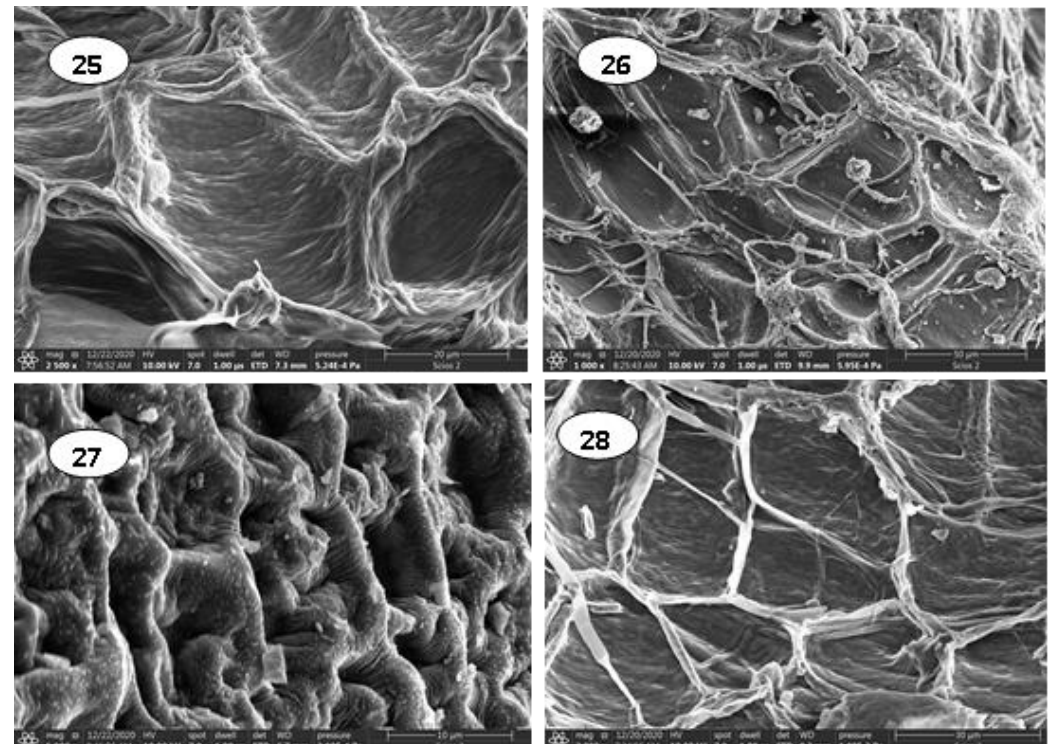

Figure 11. SEM micrographs of seeds: (Enlargement of seed coat). 25. Sida alii; 26. Sida ovata; 27. Sida rhombifolia; 28. Sida spinosa. 


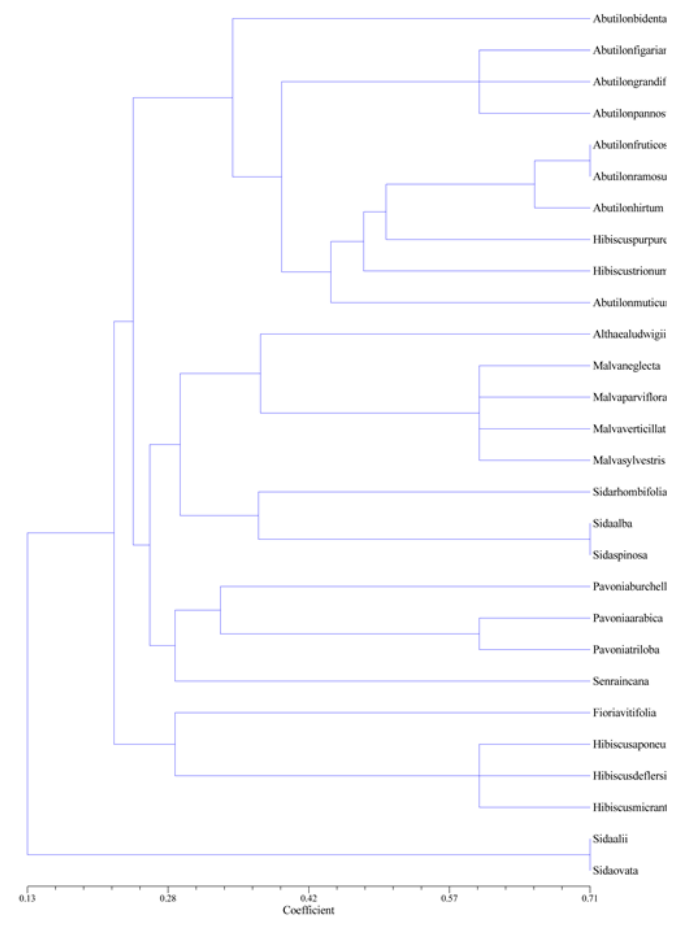

Figure 12. Dendrogram illustrating the relationships of the investigated species of subfamily Malvoideae based on seed characters.

relationship between the members of subtribe Abutilinae, based on the internal transcribed spacers of nuclear ribosomal DNA (ITS). The taxa in the Sida generic alliance from 58 species of Malvaceae were sequenced. The ITS data revealed that Abutilon and Sida were not monophyletic. Similarly, Garcia et al. (2009) used five molecular markers (ITS, matK + trnK, ndhF, trnL-trnF, and psbA-trnH) to investigate a phylogenetic hypothesis of Malva alliance (Malvaceae), and reported that Althaea, Malva, and Lavatera are highly polyphyletic. Furthermore, Celka et al. (2010) determined genetic relationships among eight Malva taxa by using ISSR and ISJ markers. These species were classified into two groups consistent with the sections Bismalva ( $M$. excisa, $M$. alcea, and M. moschata) and Malva ( $M$. neglecta, $M$. sylvestris, $M$. pusilla, and $M$. verticillata). According to the characters of seed, the studied taxa of Malva, Althaea, and Sida were classified in one cluster that split into three groups.

All of the three genera have asymmetric seed, obtuse apex, reniform base seed, brown and glabrous seed, raised-thin anticlinal boundaries, and flat periclinal cell wall. The results of seed characters support the placement of $M$. neglecta, $M$. sylvestris, $M$. parviflora, and $M$. verticillata with both of Althaea and some species of Sida in tribe Malveae. The results of this study agree with Bentham and Hooker (1862), Hutchinson (1967), Celka et al. (2010), Reveal (2012), and Jun Qiana et al. (2020), for treating them as tribe Malveae and agree with Fryxell (1997) and Aguilar et al. (2003) in the genus Sida is heterogeneous because the species of genus are distributed in two clusters.

\section{Tribe Hibisceae}

Reveal (2012), and Bayer an Kubitzhi (2003) placed the Pavonia, Senra, Fioria and Hibiscus in the tribe Hibisceae. Fryxell (1997) investigated Pavonia of the new world and reported that all species of this genus contain the same base chromosome number $(x=7)$. However, some of the authors have placed Pavonia in a separate tribe Ureneae (Bentham and Hooker 1862; Schultze-Motel 1964; Hutchinson 1967) but Takhtajan (2009) and Reveal (2012) placed this genus within Hibiscus in the tribe Hibiscieae. In addition, Bentham and Hooker (1862), and Hutchinson (1967) treated Senra in the tribe Hibiscieae. Our data support the previous work of Senra and Pavonia in tribe Hibiscieae (Reveal, 2012), because it has a unique characters and further support comes from the seed characters that indicates that is homogenous cluster with 0.60 genetic similarities. These characters are obtuse seed apex, concave seed sides, brown seed and raised-thick anticlinal boundaries. Concerning with Fioria, the results of seed characters support the previous work of treating Fioria in a tribe Hibiscieae in congruence with those authors. In addition, Bentham \& Hooker (1862), Hutchinson (1967), and Reveal (2012) treated Hibiscus in the tribe Hibisceae. Hochreutiner (1900) classified the genus Hibiscus into 12 sections and concluded that Hibiscus is very heterogeneous and needs more attention. Moreover, Cufodontis (1948) studied Hibiscus species in Africa and treated $H$. purpureus, $H$. micranthus, and $H$. deflersii in section Bomycella. The results of this study do not support the monophyly of the genus Hibiscus, because the species of the genus distributed in two clusters. The first cluster includes $\mathrm{H}$. aponerous, $\mathrm{H}$. micranthus, $\mathrm{H}$. deflersii and Fioria vitifolia, with 0.60 genetic similarities. All of these species have cordate reniform seed, concave seed sides, asymmetric, reniform hilum, and raised-thin, ridged anticlinal boundaries. The second group includes $A$. fruticosum, A. ramosum, A. hirtum, A. muticum, Hibiscus purpureu and $H$. trionum with 0.70 genetic similarities based on their dark brown seed, reticulate-foveate, verucate surface pattern, raised-thick, ridged, and rough anticlinal boundaries. The results of this study suggest that the species of Hibiscus form a polyphyletic group. Therefore, these 
results are partially in line with Bayer \& Kubitzhi (2003), and Reveal (2012), and in congruent with the findings of Cufodontis (1948), Hutchinson (1967) and Fryxell (1997) in the monophyly of Pavonia.

\section{Materials and Methods}

\section{Plant materials}

The current study was based on samples gathered from herbarium sheets deposited in the herbaria of King Saud University (KSU), Umm Al Qura University (UQU, proposed acronym), as well as Millennium Seed Bank from Royal Botanic Gardens (K), acronyms based on Thiers (2019). Mature seeds of the 28 Saudi Arabian species (represented 8 genera: Abutilon, Althaea, Fioria, Hibiscus, Malva, Pavonia, Senra, and Sida) were selected for morphological examinations. A complete list of the species investigated in this study is provided in Tables $1 \& 2$.

\section{Seed micro-morphological examinations}

Seed micro-morphological details were examined and photographed using a JOEL JSM 5200 LV SEM located in the central laboratory of Umm Al-Qura University, Faculty of Applied Science, Makkah, Saudi Arabia. Dry seeds were prepared by mounting them directly onto clean stubs using double-sided adhesive tape, followed by coating with a thin layer of gold in an ion-sputtering device (JEOL JFC E1100). The terminology of seed coat characters were used according to (Barthlott, 1981; Boesewinkel and Bouman, 1984) with some modifications.

\section{Statistical analysis}

A total of 13 characters were measured in each species. Statistical analysis was carried out according (Rohlf, 2005) using NTSYS-pc 2.0 software. A dendrogram was constructed based on similarity matrix data by using the unweighted pair-group method with arithmetic mean (UPGMA) employing sequential, agglomerative, hierarchical, and nested clustering. The characters that scored and obtained from seed morphological characters are shown in Appendix.

\section{Conclusion}

In conclusion, the present study supports the use of seed morphological characters as a parameter for species identification. The results suggest a close relationship between different tribes of Malvaceae because there are different types of seed surfaces, seed shapes and epidermal cells similar each other from traditional tribes. Seed coat morphology provided some evidence for intrageneric classification and corresponded with the phylogenetic results of Bayer \& Kubitzhi (2003) and Reveal (2012). In addition, the results of seed topography showed four main categories of seed surface patterns reticulate, foveate, alveolate, and rugose. Reticulate type is distinguished Abutilon from the rest of the taxa, and the alveolate type can distinguish species of Hibiscus from the Malva. Finally, seed coat analysis confirmed that developmental variation in seed characters is taxonomically useful, because not only it gives us a better understanding of sculpture development, but also because it allows us to formulate the taxonomy of Malvaceae on the genera and tribal levels, and it is useful for constructing an identification key.

\section{Acknowledgement}

The authors would like to thank the Research and Development Grants Program for National Research Institutes and Centers (GRANTS), Graduate Research Program, King Abdulaziz City for Science and Technology (KACST), Kingdom of Saudi Arabia, grant number (Project ID: 1-18-01-007-0001) for the financial funding. In addition, we are thankful to the herbarium director and curator of the King Saud University and Agriculture and Water Research Center, Riyadh, (KSU and RAWRC).

\section{References}

Abdel Khalik K (2002) Biosystematic studies on Brassicaceae (Cruciferae) in Egypt. Wageningen University. publish by Wageningen University.

Abdel Khalik K (2010) Seed coat morphology and its systematic significance in Juncus L. (Juncaceae) in Egypt . J Syst and Evol. 48(3): 215-223

Abdel Khalik K (2013) Systematic implications of seed coat diversity in some representatives of the genus Ipomoea (Convolvulaceae). Turk J Bot. 37 (5): 811-824

Abdel Khalik K (2016) Seed morphology and surface microstructure of the genus Plectranthus L. (Lamiaceae) in Arabian Peninsula with highlighting on their systematic implications. Aust J Crop Sci. 10 (9): 1222-1231.

Abedin S, Al-Yahya M, Mossa J, Al-Said M (1999) Malvaceae. In: "Flora of the Kingdom of Saudi Arabia". Chaudhary SAs, (ed.). Ministry of Agriculture and Water, Riyadh.

Abid R, Ather A, Qaiser M (2016) Seed morphology and its taxonomic significance in the family Malvaceae. Pak J Bot 48: 2307-2341.

Alverson WS, Whitlock A, Nyffeler R, Bayer C, Baum DA (1999)

Phylogeny of the core Malvales: evidence from ndhF sequence data. American J Bot. 86: 1474-1486.

APG (2003) An update of the Angiosperm Phylogeny Group classification for the orders and families of flowering plants. Bot J Linn Soc. APG II: 399-436.

APG (2009) An update of the Angiosperm Phylogeny Group classification for the orders and families of flowering plants. Bot J Linn Soc. APG III: 105-121.

Barthlott W (1981) Epidermal and seed surface characters of plants: systematic applicability and some evolutionary aspects. Nord J Bot. 1: 345-355.

Bates DM (1968) Generic relationships in the Malvaceae, tribe Malveae. Gentes Herbarium. 10: 117-135.

Bayer C, Fay MF, De bruijn AY, Savolainen V, Morton CM, KubitzkI K, Alverson WS, Chase MW (1999) Support for an expanded family concept of Malvaceae within a recircumscribed order Malvales: A combined analysis of plastid atp B and rbc L DNA sequences. Bot J Linn Soc. 129: 267-303.

Bayer C, Kubitzki K (2003) Malvaceae. In: "The Families and Genera of Vascular Plants". Kubitzki K. Bayer Cs, (eds.). Springer, Berlin Heidelberg.

Bentham G, Hooker JD (1862). Malvaceae. In G. Bentham and J. D. Hooker 401 [eds.], Genera Plantarum, 195-213. London, England.

Boesewinkel FD, Bouman F (1984) The Seed: Structure. In: "Embryology of Angiosperms". Johri Bs, (ed.). Springer Berlin Heidelberg, Berlin.

Carvalho LDA, Machado R, Bovini M (1999) Seed coat micromorphology of Brazilian species of Schwenckia. In: 
"Solanaceae IV. Advances in Biology and Utilization". Nee M SD, Lester R, Jessop J., Hookers, (ed.). Richmond, England, Kew, Royal Botanical Garden.

Celka Z, Szczecinska M, Sawicki J (2010) Genetic relationships between some of Malva species as determined with ISSR and ISJ markers. Biodiversity: Res Conserv. 19: 23-32.

Chase MW, Christenhusz M, Fay M, Byng J, Judd WS, Soltis D, Mabberley D, Sennikov A, Soltis PS, Stevens PF (2016) An update of the Angiosperm Phylogeny Group classification for the orders and families of flowering plants. Bot J Linn Soc. APG IV: 1-20.

Chaudhary SA (1999) Flora of the Kingdom of Saudi Arabia, illustrated. Ministry of Agriculture \& Water, National Herbarium.

Collenette S (1985) An Illustrated guide to the flowers of Saudi Arabia. Scorpion publishing Ltd., London.

Cufodontis G (1948) Overview of the African Hibiscus species from section Bombycella. Annals of the Natural History Museum in Vienna. 56: 24-59.

El Naggar SM (2001) Systematic implications of seed coat morphology in Malvaceae. Pak J Biol Sci. 4: 822-828.

Erol O, Uzen E, Kucuker O (2006) Preliminary SEM observations on the seed testa structure of Gladiolus $\mathrm{L}$. species from Turkey. Int J Bot. 2: 125-127.

Fawzi NM (2011) Macro-and Micromorphological Seed Characteristics of some Selected Species of Caesalpinioicleae-Leguminosae. Res J Bot. 6: 68-77.

Fawzi NM (2018) Seed morphology and its implication in classification of some selected species of genus Corchorus L. (Malvaceae). Midd East J Agri Res. 7: 1-11.

Fryxell PA (1997) The American genera of Malvaceae. II. Brittonia. 49: 204-269.

Fryxell PA (2002) An Abutilon nomenclator (Malvaceae). Lundellia. 5:79-118.

Fuertes Aguilar J, Fryxell PA, Jansen RK (2003) Phylogenetic relationships and classification of the Sida generic alliance based on nrDNA ITS evidence. Syst Bot. 28: 352-364.

García EP, Schönswetter P, Fuertes Aguilar J, Nieto Feliner G, Schneeweiss GM (2009) Five molecular markers reveal extensive morphological homoplasy and reticulate evolution in the Malva alliance (Malvaceae). Mol Phylo Evol. 50: 226-239.

Heywood VH (1993) Flowering plant families of the world. Oxford University Press, New York.

Hutchinson J (1967) The Genera of Flowering Plants (Angiospermae), vol. II. 461 Clarendon Press, Oxford.

Judd WS, Manchester SR (1997) Circumscription of Malvaceae (Malvales) as determined by a preliminary cladistic analysis of morphological, anatomical, palynological, and chemical characters. Brittonia. 49: 384405.

Jun Qiana B, Zefei D, Jianga Y, Baozhong Duana B (2020) The complete chloroplast genome sequence of Althaea rosea
(L.) Cavan. (Malvaceae) and its phylogenetic analysis. Mitoch DNA. Part B. 5(2):1433-143.

Karakish EA, Al-Ruzayza S, Khalik KA (2020) Comparative anatomical studies of some species of family Malvaceae from Saudi Arabia and its systematic significance. Egypt J Exper Biol. 16: 203-221.

Kearney TH (1951) The American genera of Malvaceae. Amr Mid Nat. 46: 93-131.

Krebs G (1994) Taxonomic studies in the subtribe Malvinae. Feddes Repot. 105:7-18.

La Duke JC, Doebley J (1995) A chloroplast DNA based phylogeny of the Malvaceae. Syst Bot. 20: 259-271.

Luque Palomo MT, Devesa Alcaraz J A (1986) Contribución al estudio citotaxonómico del género lavatera (malvaceae) en España. Lagascalia. 14 (2), 227-239.

Masullo FdA, Siqueira SFH, Barros CF, Bovini MG, De Toni KL (2020) Fruits of neotropical species of the tribe Malveae (Malvoideae-Malvaceae): macro-and micromorphology. Acta Bot Bra. 34: 301-311.

Mattei GE (1915) Studi sugli Abutilon dell'Africa Orientale. Bollett R.Orto Bota Pale 69-102.

Migahid AM (1978) Flora of saudi Arabia. Riyadh University Publication RIYADH

Özbek F, Uzunhisarcikl E (2020) Mericarp and Seed Morphology of the genus Althaea L. (Malvaceae) in Turkey. Gazi Univ J Sci. 1-1.

Ray MF (1995) Systematics of Lavatera and Malva (Malvaceae, Malveae), a new perspective. PI Sys Evol. 198: 29-53

Reveal JL (2012) An outline of a classification scheme for extant flowering plants. Phytoneuron.. 37: 1-221.

Rohlf, F. (2005) Geometric morphometrics simplified. Trends in Ecology \& Evolution. 20(1):13-14

Schultze-Motel, W. (1964) in Melchior, H. (ed.). A. Engler's "Syllabus der Pflanzenfamilian". 12th ed, Gebrüder Borntraeger Verlag, Berlin.

Taia, W. (2009) General view of Malvaceae Juss. sl and taxonomic revision of genus Abutilon Mill. in Saudi Arabia. Journal of King Abdulaziz University-Science 21: 349-363.

Takhtajan A (2009) Flowering plants. 2nd ed. Berlin: Springer-Verlag.

Tate JA, Aguilar JF, Wagstaff SJ, La Duke JC, Bodo Slotta TA, Simpson BB (2005) Phylogenetic relationships within the tribe Malveae (Malvaceae, subfamily Malvoideae) as inferred from ITS sequence data. Am J Bot. 92(4): 584-602.

Thiers B (2019) Index herbariorum. A global directory of public herbaria and associated staff. New York Botanical Garden's Virtual Herbarium "Published on the Internet:" http://sweetgum.nybg.org/science/ih. Accessed February

Zareh M, Faried A Farghaly N (2017) Micromorphological studies on the genus Lotus L. (Fabaceae: Loteae) from Egypt. Turk J Bot. 41: 273-288. 